\title{
ROLE OF SCIENCE "INFORMATION LAW" IN IMPROVEMENT OF NATIONAL LAW SYSTEM IN THE CONDITIONS OF INFORMATIVE SOCIETY AND DIGITAL ECONOMY
}

\author{
Aristova I. V., Chernadchuk T. $O$.
}

\section{INTRODUCTION}

About the importance of solving the problem of improving the functioning of National law system in the conditions of the extension of informative society and digital economy in Ukraine the attention is pointed in many regulations and legal acts, such as Law of Ukraine "On the Basic Principles of Information Society Development in Ukraine for 2007-2015", Resolution of the Verkhovna Rada of Ukraine "As for the Recommendations of the parliamentary hearings on the topic "Legislative support for the development of the information society in Ukraine", July 3, 2017², the Order of the Cabinet of Ministers of Ukraine "On approval of the Concept of digital economy and society of Ukraine for 2018-2020 and its implementation”, January 17, 2018 № 67-p ${ }^{3}$. Simultaneously and a special paragraph of Agreement about the association between Ukraine and $\mathrm{EU}^{4}$ devoted to the different points of digital society including the directions of improvement the law system and legislation system of Ukraine. On the agenda of National Academy of Legal Science (further NALS) of Ukraine constantly are the questions of searching new approaches as for forming and functioning national legal system and its integral part - the system of law of Ukraine. We think that that the above confirms the relevance of the theme of the article.

1 Про Основні засади розвитку інформаційного суспільства в Україні на 2007-2015 роки: Закон України від 09.01.2007. URL: https://goo.gl/oPp05P (дата звернення: 15.01.2021)

2 Про Рекомендації парламентських слухань на тему: «Законодавче забезпечення розвитку інформаційного суспільства в Україні» : Постанова Верховної Ради України від 3 лютого 2017 року № 1565-VII. Відомості Верховної Ради Украӥни. 2014. № 33. Ст. 1163.

${ }_{3}$ Про схвалення Концепції розвитку цифрової економіки та суспільства України на 2018-2020 роки та затвердження плану заходів щодо її реалізації: Розпорядження Кабінету Міністрів України від 17 січня 2018 р. № 67-p URL: https://goo.gl/zoUzYE (дата звернення 15.01.2021)

4 Угода про асоціацію між Україною, 3 однієї сторони, та Європейським Союзом, Європейським співтовариством 3 атомної енергії і їхніми державамичленами, 3 іншої сторони: Міжнародний документ від 27 червня 2014 року URL: https://goo.gl/6BtyуH (дата звернення 15.01.2021) 
In our opinion, the scientific society of Ukraine must activate research in the mentioned direction by NALS including modern tendencies of development of digital society and digital economy in Ukraine.

The aim of the article is to determine the peculiarities of influence some factors of digital economy and digital law on the society relations in the conditions of digital society in Ukraine and making suggestions as for improvement the system of national law in the new conditions of present life.

\section{Genesis of the scientific research as for forming law system}

The conducted research allowed to prove that the that developments in the legal system of Ukraine exist in the field of scientific interests not only of specialists in the field of general theory of state and law and comparative jurisprudence, but also in the field of branch legal sciences. For example, the analysis of results given in the work ${ }^{5}$ allowed to persuade in the following. The authors consider the legal system as a set of "orderly and mutually agreed rules of law, which characterizes its internal structure, an integral part of the legal system"6. Simultaneously, the attention is pointed on the definition signs which characterize system of law. We think as the important that according to the first sign, the inner structure of the law is conditioned by the objective development of society relations ${ }^{7}$. So, it means we can assume that we are talking about the objective development of information relations in the development of the information society, and the relevant effective regulations that can have a proper impact on public information relations. Despite the above, the authors do not include in the list of structural elements of the legal system (either norms or branches of law) information component. Noting the systematic society relations, scientists come to conclusion that this is what gives the law systemic properties and determines its structure, which is a holistic union of relatively independent, but interconnected elements of law ${ }^{8}$.

In our opinion, the main reason of systematic law lies in other - it is the purpose for which they interact ("cooperate" - in Russian) elements of law system. More detailed about this reason will be said in the following part of the article. At the same time, the article shares the opinion that the effectiveness of legal regulation of public relations directly depends on the degree of objectivity and logic of the structure of law ${ }^{9}$.

In our opinion, is very useful as from the scientific so from the practical point of view the research of L.A. Luts appear as for the definition and

${ }^{5}$ Теорія держави і права. Академічний курс: підручник. За ред. О. В. Зайчука, Н. М. Оніщенко, В. С. Журавського та ін. 2-е вид., перероб і допов. К.: Юрінком Інтер, 2008. C. 386-395.

Там само. С. 387.

7 Там само.

${ }^{8}$ Теорія держави і права. Академічний курс: підручник / за ред. О. В. Зайчука, Н. М. Оніщенко, В. С. Журавського та ін. 2-е вид., перероб і допов. К.: Юрінком Інтер, 2008. C. 387.

Там само. С. 389. 
structure of law system of the society ${ }^{10}$. Absolutely agree with L.Luts as for the role of systematic analysis in development the definition "legal system of society", scientific works in legal cybernetics and also those works which show the logic of application the definition "system" for the law, legislation and other legal phenomena and processes in understanding the specified phenomenon $^{11}$.

Really, the analysis of the doctrinal juridical research as for the different aspects of legal system allowed to persuade in the importance those works which consider the problems of correlation the definitions "legal system", "law" ("system of law") regularity of development of notional, functional, informative, administrative aspects (especially, scientific works ${ }^{12,13,14,15}$ ). At the same time, an important conclusion, from our point of view, is the provision on the need to analyze certain aspects of this phenomenon (in particular, the "system of law") on the basis of the concept of "legal system" ". Analyzing the forming definition "legal system" L. Luts gives the position by Yu. Tykhomyrov: a definition "legal system" is the theoreticalmethodical basis for the development of idea about legal phenomena and generic concept for such types of definitions as "system of legislation", "laws", "system od law", etc. ${ }^{17}$. As noted L. Luts this definition, according to a number of authors, is a dynamic, functioning law and is a different concept from the legal system ${ }^{18}$.

Acquaintance with the position of A. Venherov ${ }^{19}$ allowed to establish that the understanding of law as a system of legal norms, endowed with the appropriate characteristics and features, contributes to the selection of such features of law as its system and structure. At the same time, the study of the system and structure of law is important not only for scientific but also for

10 Луць Л. А. Європейські міждержавні правові системи та проблеми інтеграції 3 ними правової системи України (теоретичні аспекти): монографія. К.: Ін-т держави і права ім. В. М. Корецького НАН України. 2003. С. 28-60.

11 Алексеев С.С. Советское право как система: методологические принципы исследования. Советское государство и право.1974. № 7. С. 15-22.

${ }_{12}$ Алексеев С.С. Право и правовая система. Советское государство и право. 1980. № 1. C. 4-9.

${ }_{13}$ Керимов Д.А. Философские основания политико-правовых исследований. М.: Изд-во «Мысль» 1986.332 с.

${ }^{14}$ Колосова Н.М. Интегративная функция правовой системы : автореф. дисс... канд. юрид. наук. М.1990. 22 с.

15 Рассолов М.М. Теоретические проблемы управления и информатики в сфере права : автореф. дисс... канд. юрид. наук. М.1990. 23 с.

16 Луць Л. А. Європейські міждержавні правові системи та проблеми інтеграції 3 ними правової системи України (теоретичні аспекти): монографія. К.: Ін-т держави і права ім. В. М. Корецького НАН України. 2003. С. 31.

${ }_{17}^{17}$ Тихомиров Ю.А. Публичное право. М. Издательство БЕК.1995. С. 212.

18 Луць Л. А. Європейські міждержавні правові системи та проблеми інтеграції 3 ними правової системи України (теоретичні аспекти): монографія. К.: Ін-т держави і права ім. В. М. Корецького НАН України. 2003. С. 32.

19 Венгеров А. Б. Теория государства и права: учеб. для юридических вузов. 8-е изд. М.: Изд-во «Омега-Л». 2011. С. 433-437. 
purely practical purposes. According to A. Venherov the system properties of an object mean the mandatory presence in this object of elements that are organically connected with each other, interact with each other. In addition to the elements and their connections, the scientist believes, the system approach highlights the nature of these connections, their content, studies the system-forming factors, determines the levels of the system, its complexity, etc. ${ }^{20}$. The author also puts attention on the long-lasting search in the theory of law system-forming society as the self, separately, so in totality, complex $^{21}$. In the article will be used another approach as for the systemforming factors which will be considered in the next part of the article.

Of course, interesting both from a scientific and practical point of view will make the study of $\mathrm{R}$. Melnyk who is a representative of the branch of legal science ("administrative law") in relation to the legal system ${ }^{22}$. First of all, it should be noted the constructive use of historical-legal and comparative-legal methods of studying the development of domestic scientific views on understanding the system of law and its place in this system of administrative law. We share the position of the scientist that such a methodological arsenal allowed: "to compare today's developments on this issue with the results of previous years and evaluate the achievements in this direction; explain certain features of the national legal system in comparison with the system of foreign law; outline, taking into account historical experience, the prospects for the development of the national legal system; to lay the necessary foundation for the study of the system of Soviet administrative law"23.

From the R. Melnyk's point of view, by the system is necessary to understand the whole complex of delimited, interconnected and interacting with each other elements - legal norms. Simultaneously, the scientist does not agree with the basis for the legal norms classification which connects with the peculiarities of society relations which form self-social system; with recognition law as the derived from society relation phenomenon ${ }^{24}$. The scientist proposes the determine the system of law (in the most common variant) as "a set of normatively undefined, as well as normatively defined regulators, which are used to influence the behavior and consciousness of participants in public relations, 25 .

R. Melnyk defends the position that the system of law is the hierarchical formation, within which can be divided into two main subsystems - the system of private and public law, each of which, in turn, contains a systematic formation of branch norms (branches of law) ${ }^{26}$. At the same time, the author

${ }^{20}$ Там само. С. 433.

${ }^{21}$ Там само. С. 437.

22 Мельник Р. С. Система адміністративного права України : монографія. Харків : Вид-во Харків. нац. ун-ту внутр. справ, 2010. С. 27-61.

${ }^{23}$ Там само. С. 28.

${ }^{24}$ Там само. С. 50.

${ }^{25}$ Там само. C. 53.

${ }^{26}$ Там само. C. 61. 
draws attention to the inexpediency of understanding the internal structure of the system of private and public law, based on one criterion (subject of legal regulation), which in fact cannot be common to both at the same time ${ }^{27}$.

Of course, the special attention needs the position of the scientist as for the appearing new branches of law and their places in national system of law. From one side, we agree with R. Melnyk position that is the quantity of branches determine by the conditions of functioning democratic, social and legal state ${ }^{28}$. From another side, some questions appear as for the criteria for selecting these conditions; ways to comply with them; understanding the concept of integrity; structure of the Special administrative law, in particular concerning consideration of information, ecological law by its sub-branches, etc. In our opinion, the arguments presented by the author regarding the indisputability of his position do not appear sufficiently substantiated.

Summarize the results of existing doctrinal research allows us to realize the lack of a well-established position on understanding the system of national law and approaches to its improvement, interpretation of the basic provisions of the systemic approach, grounds for forming new branches of law and their place in the legal system of Ukraine digital economy in Ukraine. That's why we consider it appropriate to propose our own approach to clarify the issues raised. At the same time, our research will constructively take into account the existing theoretical and methodological developments of both legal scholars and specialists in the field of systems approach and information technology.

In previous publications, for example, in the article ${ }^{29}$ it was already noted that the digital economy is one of the features of the information society, which, in turn, requires a rethinking of the role of law, directions of development of branches of law and their interaction. At the same time, the new conditions of today determine the intensification of interdisciplinary research, which at one time drew the attention of lawyers - specialists in the field of information law ${ }^{30}$, and today - this is called for by experts in the

27 Мельник Р. С. Система адміністративного права України : монографія. Харків : Вид-во Харків. нац. ун-ту внутр. справ, 2010. С. 59.

${ }^{28}$ Там само. С. 328.

29 Арістова І.В., Карпик Ю.А. Вплив цифрової економіки та європейської інтеграції на правотворчість у сфері інтелектуальної власності в умовах розбудови інформаційного суспільства та інформаційного законодавства в Україні. Modern researches: progress of the legislation of Ukraine and experience of the European Union: Collective monograph. Riga : Izdevniecība "Baltija Publishing". 2020. P. 1. P. 255-288. DOI: 10.30525/978-9934-588-43-3/1.16 Available from: http://dx.ua/8eBpr

30 Арістова І. В., Курило В.І., Калугін О.Ю. Впровадження інформаційнокомунікаційних технологій в аграрний сектор економіки України: організаційноправовий аспект: монографія / За заг. ред. І. В. Арістової. К.: Редакційновидавничий центр НУБіП України. 2014. 193 с.

${ }^{31}$ Бєляков К.І. Інформатизація в Україні: проблеми організаційного, правового та наукового забезпечення : монографія. К. : КВІЦ, 2008. 576 с. 
field of information technology ${ }^{32}$. It is primarily about the use of knowledge of general theory of law, information law, intellectual property law, general theory of functional systems, the latest knowledge of information technology, digital economy.

Analysis of the literature, in particular the monograph ${ }^{33}$, revealed that the main tools of the digital economy are blockchain, blockchain token, digital asset and smart contract.

It should be emphasized that the study of their content and functional characteristics ${ }^{34}$ contributed to the understanding of the significant dynamics of the formation of information relations. Indeed, because a blockchain is a structured database, a "chain of blocks", where each is linked to the previous one and contains a set of records (information about events, people, objects, transactions, serial numbers, issued credits, etc. $)^{35}$, the emerging social relations during the transaction of information or access to it are informative character. It was found that the constant increase in emerging (initiated by various entities) information relations is due to the embedding in blockchain technology very important principles of operation: absolute transparency, "trustworthy" nature of the system, openness and security of user data, accessibility to transaction history of all participants, distribution register ${ }^{36}$. At the same time, the emergence of the methodology for diagnosing the characteristics of the token of the distributed register (blockchain) for compliance with the digital asset ${ }^{37}$ allowed to guarantee proper security to owners of digital assets and, as a result, intensified the emergence of information relations.

We consider it necessary to remind that: 1) blockchain token is a unit of blockchain accounting ${ }^{38} ; 2$ ) a digital asset is an information resource derived from the right to value and one that circulates in a distributed register in the form of a unique identifier ${ }^{39}$; 3) the complex properties of the blockchain token are reduced to one important function - access to the information resource, which, in turn, provides access to a set of rights to value, which

${ }^{32}$ Кудь О.О., Кучерявенко М.П., Смичок С.М. Цифрові активи та їх економікоправове регулювання : монографія. Харків : Право, 2019. 384 с.

${ }^{33}$ там саме.

34 Арістова І.В., Карпик Ю.А. Вплив цифрової економіки та європейської інтеграції на правотворчість у сфері інтелектуальної власності в умовах розбудови інформаційного суспільства та інформаційного законодавства в Україні. Modern researches: progress of the legislation of Ukraine and experience of the European Union: Collective monograph. Riga : Izdevniecība "Baltija Publishing", 2020. P. 1. P. 255-288. DOI: 10.30525/978-9934-588-43-3/1.16 Available from: http://dx.ua//eBpr

35 Что такое блокчейн простыми словами. URL: https://prostocoin.com/blog/ blockchain-guide (дата звернення: 15.01.2021)

${ }^{36}$ Кудь О.О., Кучерявенко М.П., Смичок Є.М. Цифрові активи та їх економікоправове регулювання : монографія. Харків : Право, 2019. С. 14.

${ }^{37}$ Кудь О.О., Кучерявенко М.П., Смичок С.М. Цифрові активи та їх економікоправове регулювання : монографія. Харків : Право, 2019. С. 54.

${ }^{38}$ Там само. С. 47.

${ }^{39}$ Там само. С. 351. 
means property, property and non-property rights, securities, services, works, digital assets, etc. ${ }^{40}$. Given this function of the blockchain token, there is every reason to believe that there are complex social relations, in particular, information-property, in which information relations play a supporting (supporting) role. As for the impact of the smart contract tool on the formation of new information relations, this issue has already been covered in another of our research work ${ }^{41}$.

Thus, there are objective prerequisites for the dynamic development of information public relations in the development of the information society in Ukraine, which, in turn, may require a relevant effective regulatory framework, which is mentioned, for example, in ${ }^{42}$. We consider it is important to emphasize that the previous author's publication ${ }^{43}$ justified the need to form a systemic mechanism for the protection of public relations, integral components of which are legal protection and technological protection (using the tools of the digital economy). It is clear that the improvement of the functioning of this mechanism should be influenced by concerted action to improve each of the components of the mechanism. In this article we propose to focus on developing an approach to improve the first component - the legal regulation of public relations in the information society and digital economy in Ukraine, especially the system of national law in the new conditions of today.

\section{Influence of science "information law" on the development of law concept}

Turning to the presentation of the author's approach, we consider it necessary first of all to determine its initial provisions: 1) the system of national law is an integral part of its super system - the national legal system; 2) the system of national law is designed to perform one of the functions of the super system in the information society and digital economy in Ukraine; 3) the system-forming factor of the system of national law is the goal that must be achieved; 4) the system of national law, in turn, is a super

${ }^{40}$ Там само. С. 73.

41 Арістова І.В., Карпик Ю.А. Вплив цифрової економіки та європейської інтеграції на правотворчість у сфері інтелектуальної власності в умовах розбудови інформаційного суспільства та інформаційного законодавства в Україні. Modern researches: progress of the legislation of Ukraine and experience of the European Union: Collective monograph. Riga : Izdevniecība "Baltija Publishing", 2020. P. 1. P. 255-288. DOI: 10.30525/978-9934-588-43-3/1.16 Available from: http://dx.ua/8eBpr

${ }_{42}$ Теорія держави і права. Академічний курс: підручник / За ред. О. В. Зайчука, Н. М. Оніщенко, В. С. Журавського та ін. 2-е вид., перероб і допов. К.: Юрінком Інтер, 2008. C. 387.

Арістова І.В., Карпик Ю.А. Вплив цифрової економіки та європейської інтеграції на правотворчість у сфері інтелектуальної власності в умовах розбудови інформаційного суспільства та інформаційного законодавства в Україні. Modern researches: progress of the legislation of Ukraine and experience of the European Union : Collective monograph. Riga : Izdevniecība "Baltija Publishing", 2020. P. 1. P. 255-288. DOI: 10.30525/978-9934-588-43-3/1.16 Available from: http://dx.ua/8eBpr 
system of systems of branches of law that are designed to perform the relevant functions of the system of national law; 5) in the conditions of information society and digital economy in Ukraine the information sphere of society and information public relations are dynamically developing.

In order to form proposals for improving the system of national law in the new conditions of today, we consider it appropriate to cite certain provisions of the author's publication ${ }^{44}$, which reflects the genesis of the views of one of the authors of this article on the content of definition "integrative information sphere" and its connection with the definition "system of national law" (legal sphere) by A.Venherov determination ${ }^{45}$.

It is necessary to underline that for understanding society relations (legal relations) in information sphere the most promote the introduction in scientific circulation (back in 2012) the definition "integrative information sphere" and also investigations its structure ${ }^{46}$. Further understanding of the meaning of this concept allowed us to consider the integrative information sphere as a model of the legal sphere of society, which is «permeated» with information. This is confirmed by the fact that: 1) information is one of the most generalizing categories (in Russian - "extremely generalizing category"); 2) in essence, both social relations and legal relations are informative. We propose in the measures of science «information law» to expand "information conception of law" as the study about information essence of law, with was proposed by A.Venherov ${ }^{47}$ and supported practically by all researchers (for example, V. Kopylov ${ }^{48}$, O. Kokhanovskyi ${ }^{49}$ ).

In our opinion, it is not enough to call the legal sphere an "information system" (as suggests A. Venherov): it is necessary to study the legal sphere from the standpoint of a systemic approach. By the way, one of the authors of this work has repeatedly reported at various scientific conferences ${ }^{50}$ the results of his research on the constructive use of branch legal sciences system-

44 Арістова I. В. Теоретико-правові засади інформаційних правовідносин. Юридична відповідальність за правопорушення в інформачійній сфері та основи інформаційної деліктологї̈: колективна монографія. Київ: КВУЦ, 2019. С. 36-62.

45 Венгеров А.Б. Право и информация в условиях автоматизации управления (теоретические проблемы): автореф. дис. ... д-ра юрид. наук. Москва, 1975. 26 с.

${ }^{46}$ Арістова I.В., Чернадчук В.Д. Концепція інформаційних правовідносин: сутність та особливості використання у сфері банківської діяльності. Інформація і право. 2012. № 3 (6). С. 47-56.

47 Венгеров А.Б. Право и информация в условиях автоматизации управления (теоретические проблемы): автореф. дис. ... д-ра юрид. наук. Москва, 1975. 26 с.

${ }_{48}^{4}$ Копылов В. А. Информационное право. Учебник. М.: Юристъ, 2002. 456 с.

49 Кохановська О.В. Основні теорії у сфері інформаційних правовідносин: концепція інформаційних прав як приватноправового інституту i теорія інформаційного права як галузі права у сучасній правовій доктрині України. Приватне право. 2013 № 1. С. 186-200.

${ }_{50}$ Арістова І.В. Проблема взаємодії галузей національного права: методологічні засади. Матеріали IV Всеукраїнської науково-практичної конферениії «Актуальні питання вітчизняної юридичної науки» (м. Суми, 13-14 квітня 2017 р.). Суми: видво СНАУ, 2017. С. 42-45. 
structural method of cognition of legal phenomena, which should be considered as elements of the system. In our opinion, such a vision requires the implementation of the next important step, namely, scientific research in the direction of defining the concept of "system", which is used in jurisprudence and is based on the principles and laws of formation and development of natural systems. The substantiation of this direction of research is one of the fundamental provisions of the systems approach, according to which the "system" is the isomorphic principle that penetrates all the boundaries that have historically developed between different sciences ${ }^{51}$.

The conducted analysis of doctrinal research in the field of jurisprudence on the understanding of the concepts "system", "legal system", "legal system" (for example, work ${ }^{52}$ ) allowed us to conclude that all existing definitions of "system" is random, do not reflect the true essential properties and therefore, of course, are not constructive, that is, do not help to ask new, larger questions for the researcher. In this regard, it was considered possible to propose the use of a general theory of functional systems ${ }^{53}$ in conducting research in the legal field - the system of national law. In the previous author's work ${ }^{54}$ the position is defended that the consideration of the legal sphere as a system should be based on the following provisions of this theory.

1. A mandatory provision for all spheres of the system approach is the search and formulation of the system-forming factor. The solution of this key problem affects both the definition of "system" and the whole strategy of its application in research. It is said that in the expressions "ordered interaction", "organized interaction" there is no factor that regulates this interaction.

2. The formation of the system is subject to obtaining a specific useful result. Only the result can change an unorganized set to an organized one. Any component can be part of the system only if it contributes ("promotion" - in Russian) to the programmed result.

3. In order to achieve the result the system can "go" to the biggest changes in the interaction of its components. This means that those connections between the components of the system that do not help to obtain a useful result are eliminated from the active activity. The prediction of system behavior is facilitated by focusing on the nature of the relationships that exist between the components of the system, rather than on the components themselves. Systems that consist of parts of a completely

51 Анохин П. К. Принципиальные вопросы общей теории функциональных систем: монография. URL: https://goo.gl/hgbmvz (дата звернення 15.01.2021).

52 Луць Л. А. Європейські міждержавні правові системи та проблеми інтеграції 3 ними правової системи України (теоретичні аспекти): монографія. К.: Ін-т держави і права ім. В. М. Корецького НАН України. 2003. С. 9-60.

53 Анохин П. К. Принципиальные вопросы общей теории функциональных систем: монография. URL: https://goo.gl/hgbmvz (дата звернення 15.01.2021)

54 Арістова I. В. Теоретико-правові засади інформаційних правовідносин. Юридична відповідальність за правопорушення в інформащійній сфері та основи інформаційної деліктологї̈: колективна монографія. Київ: КВУЦ, 2019. С. 36-62. 
different nature and have completely different functions are subject to the same general laws of the organization.

It is necessary underline that the natural systems in this article determine as the standard of forming, functioning and development of any other system including system of law and system of particular branch of law that is whole agrees with the last positions of general theory of functional systems ${ }^{55}$.

As it was proposed in work ${ }^{56}$, the definition "system of law" is advisable to determine based on the definition "system": it is totality it is a set of selectively included components, in which the interaction and relationships become in the nature of the assistance ("cooperate" - in Russian) of components to obtain a focused useful result ${ }^{57}$. It's important to understand that a) component (element) of system has peculiar "degree of freedom" (connections). Useful connections always subordinate to achieve the results of the system; b) systems function as the "whole" for the achieving the useful result; c) in system which is functioning always appear emergent properties (qualitatively new); d) emergent properties of system differ from properties (their quantity) of system components ${ }^{58}$.

We emphasize that to determine the composition of the legal system; it is first necessary to establish adequate (essential) classification criteria, according to which a complete description of the system is formed. The paper proposes to focus on the essential criterion of classification - "the subject of legal regulation", in the field of public relations. Thus, the legal system is formed taking into account various spheres of public relations: the sphere of managerial relations, the sphere of public service relations, and the sphere of financial relations, the sphere of labor relations, the sphere of information relations, and others. Spheres of public relations appear as various subjects of legal regulation, are regulated by the corresponding branch norms of law (administrative, financial labor, civil, information, etc.). In this case, the rules of law (by industry) are considered as subsystems of the legal system. Since the system-forming factor of the legal system is the goal - "proper law and order in society", it is obvious that each subsystem must "contribute" to achieve this result, "useful" by interacting with other subsystems. We consider it expedient to remind that in modern conditions of development of information society not only the volume of information (in particular, legal) increases, but also its value and role in processes of social interaction is realized.

This pointed tendency, among other things, influenced the emergence of the information sphere - the sphere of public information relations, and the

55 Анохин П.К. Принципиальные вопросы общей теории функциональных систем: монография. URL: https://goo.gl/hgbmvz (дата звернення 15.01.2021)

56 Арістова I. В. Теоретико-правові засади інформаційних правовідносин. Юридична відповідальність за правопорушення в інформаційній сфері та основи інформаційної деліктології: колективна монографія. Київ: КВУЦ, 2019. С. 36-62.

Анохин П. К. Принципиальные вопросы общей теории функциональных систем: монография. URL: https://goo.gl/hgbmvz (дата звернення 15.01.2021).

${ }^{58}$ Там саме. 
rapid dynamics of information relations, and the formation of the need for their regulation through the relevant rules - the rules of information law. Moving from the general to the specific, it should be noted that the systemforming factor of the subsystem of informative law is the goal - proper law and order in a particular information field. At the same time, this purpose must be consistent with the purpose of the legal sphere (as a system) - the legal system. Given the fact that information "penetrates" into all spheres of public relations, we believe that the science of information law is designed to lead the scientific search for ways to effectively achieve the goal of formation and functioning of the legal system (legal sphere).

It is known ${ }^{59}$ that the mechanism of legal regulation (further MLR) appointed for reaching the appropriate law and order in the society. Realizing the necessity of research all stages of MLR and all legal means, we consider, it is possible to accent the attention on one of legal means - legal regulation which are analyzed in boundaries of other stage of MLR. MLR is considering on the first stage (norms making) ${ }^{60}$. It is necessary to underline that MLR and legal regulations also are investigated from the position of general theory of functional systems. Otherwise, goal is a system -forming factor.

If the goal cannot be achieved within one (simple) legal relations, the following is formed: 1) a complex legal relations, which may include homogeneous branch legal relations (for example, two information legal relations: information-information), if the goal is related to the information sphere; 2) a compound of complex legal relations, which may include heterogeneous sectoral legal relations (for example, information and administrative). The information legal relationship is the main one, because the goal is related to the information sphere, and the administrative one is security, as it helps to implement the information legal relationship. That is, it is an example of "interaction" of the information sphere and the sphere of managerial relations; 3) a compound of complex legal relationship, which may include heterogeneous branch legal relations (for example, administrative and information). The administrative legal relationship appears to be the main one, because in this case the goal is related to the sphere of managerial relations, and the informational one is security. It is also an example of "interaction" of the sphere of administrative relations with the information sphere. By the way, a similar model is formed in the case of "interaction" of the information sphere with other spheres of public relations. Thus, there is every reason to believe that the system of law ("legal sphere" - by definition of A. Venherov) is, in fact, an integrative information system (sphere) ${ }^{61}$.

59 Скакун О. Ф. Теорія держави і права (Енциклопедичний курс): підручник. Вид. 2-е, перероб. і доп. Харків: Еспада, 2009. С. 684-688.

${ }_{61}^{60}$ Там саме.

61 Арістова I. В. Теоретико-правові засади інформаційних правовідносин. Юридична відповідальність за правопорушення в інформачійній сфері та основи інформаційної деліктології: колективна монографія. Київ: КВУЦ, 2019. С. 36-62. 
Thereby, in works ${ }^{62}{ }^{63}$ was proposed to call social relations in integrative information sphere which are settled by norms of law, legal relation in information sphere. The composition of legal relations is the following: 1) simple (branch) relations - administrative, civil, financial, labour, information ("pure") and others, which can have as a main so a providing character; 2) compound (branch) legal relations - administrative administrative, civil - civil, information - information, etc.; 3) compound (complex) legal relations in which information ("pure") legal relations become main ones - information - administrative, information - labour, information administrative - information and others; 4) compound (complex) legal relations in which information ("pure") legal relations become providing ones administrative - information, property - information, others ${ }^{64}$.

Of course, in case of appearance compound (complex) legal relations, for example, from the first simple branch legal relations (administrative) and other simple branch legal relations (information) form administrative - information legal relations. Herewith administrative - information legal relations are compound management - information relations which have been regulated by norms of administrative and information law. Simultaneously, compound (complex) information - administrative legal relations are compound information - management relations which have been regulated by norms of information and administrative law. We remind "pure" information legal relations are just information ("pure") relations which have been regulated by norms of information law ${ }^{65}$. By the way, just information ("pure") relations become society relations in the circulation of information - making, collecting, getting, processing, storing, using, extension and saving ${ }^{66}$.

Thus, the conducted research within this article allowed to develop the "information concept of law" A. Venherov in the information society and digital economy in Ukraine. It is proved that the "information" of the national law system is manifested both in the information essence of any norm of law (civil, administrative, financial, labour, and other law) and in strengthening the interaction of any norms of law with the rules of information law in the new conditions the present. It is necessary to underline, that in boundaries of scientific school in information law led by I.Aristova were done relative research that proved such conclusion,

62 Там само.

63 Арістова І.В., Чернадчук В.Д. Концепція інформаційних правовідносин: сутність та особливості використання у сфері банківської діяльності. Інформація і право. 2012. № 3 (6). С. 47-56.

64 Арістова I. В. Теоретико-правові засади інформаційних правовідносин. Юридична відповідальність за правопорушення в інформаційній сфері та основи інформаційної деліктології: колективна монографія. Київ: КВУЦ, 2019. С. 36-62.

Арістова І.В., Чернадчук В.Д. Концепція інформаційних правовідносин: сутність та особливості використання у сфері банківської діяльності. Інформація і право. 2012. № 3 (6). С. 47-56.

${ }^{66}$ Там само. 
especially, works ${ }^{67,68,69,70}$. Such approach allowed adequately responds on interruptions of legal relation in information society, significant sing of which is digital economy with the appropriate digital instruments.

\section{CONCLUSIONS}

The achieving the purpose of the research is confirmed by the following provisions.

1. It was found out, that necessity to adapt the system of national law to new realities in connection with the emergence of new and development of existing social relations in the information society and digital economy in Ukraine. It is established that: a) in the new conditions of today the internal structure of the legal system does not take into account the objective development of social relations; b) the study of the system and structure of law is important not only for scientific but also for purely practical purposes; c) there is no established position of scientists on understanding the system of national law and approaches to its improvement in the information society and digital economy.

2. We convinced that the latest tools of the digital economy (blockchain, token, digital asset, smart contracts) determine the dynamic development of information public relations and the information sphere (as one of the spheres of society). The expediency of complex use of technical and legal means of regulating public relations in the digital economy, which is one of the features of the information society, is realized.

3. The initial provisions of the author's approach to the improvement of legal means of regulating public relations in the new conditions of today are determined. It is proposed to develop the "information concept of law" A. Venherov, which was reflected in the consideration of the model of the system of national law as an integrative information sphere, which is a systemic formation. The expediency of studying the system of national law is argued, using the provisions of the general theory of functional systems and taking into account the development of natural systems, which are considered as a standard for the formation of any system.

4. It was offered to determine the composition of the system of national law to take into account the distribution of integrative information sphere according to the criterion of classification - "subject of legal regulation", taking into account the dynamic development of information relations in the digital economy. The components of the system of national law are

${ }^{67}$ Арістова І.В. Система права України в умовах інформаційного суспільства та цифрової економіки. Приватне та публічне право. 2020. № 3. С. 45-51.

68 Чернадчук Т. О. Актуальні питання інформаційних правовідносин у банківській сфері: монографія / За заг. ред. І. В. Арістової. Суми: Вид-во СНАУ, 2011. 162 с.

$6 \dot{9}$ Чернадчук Т.О. До питання захисту інформації, віднесеної до податкової таємниці. Публічне право. 2016. № 4 (24). С. 109-115.

70 Чернадчук Т.О. До питання концепції інформаційних правовідносин в бюджетній сфері. Публічне право. 2017. № 2 (22). С. 109-115. 
established: the subsystem of administrative law, the subsystem of civil law, the subsystem of agrarian law, the subsystem of financial law, the subsystem of information law, etc. It was found that the system-forming factor is the goal - proper law and order in society in a digital economy.

5. It was justified to establish the structure of the system of national law, it is necessary to determine the relationship of mutual cooperation between the various subsystems (the composition of the system) in order to achieve a certain goal. It is proposed to investigate the formation of links between subsystems by modeling the process of achieving law and order in society the use of the mechanism of legal regulation (within the second stage).

6 . On the model examples we persuaded in the digital economy, the subsystem of information law, which is in constant contact with other subsystems of the national law system, is becoming increasingly important. The need to update research to ensure the proper level of law and order within the science of "information law" is recognized.

7. We consider it necessary to continue research in the context of practical application of the information concept of law, in particular, to regulate public relations in the information economy in Ukraine, as well as the introduction of its tools (blockchain technology, digital asset, smart contract, etc.).

\section{SUMMARY}

This article is devoted to the investigation of system property of law of Ukraine and its structure in the condition of information society and digital economy in Ukraine. It is justified the necessity of activation scientific legal research as for the search of innovative approaches for the effective forming and functioning national legal system and its integral part - system of law of Ukraine including modern tendencies of country development. As for the achievement of this goal, historical-legal, comparative-legal, systemic, logical-semantic research methods were constructively used.

It was established that there is a lack of a well-established position of legal scholars on understanding the system of national law and approaches to its improvement in a digital economy. The author's approach to clarifying the understanding of the concept of "system" and its use to improve the legal system of Ukraine is proposed. The role of digital economy tools in strengthening the dynamics of formation of information public relations and information sphere is substantiated. The expediency of building an integrative information sphere as a model of the legal system of Ukraine is proved.

It was defined the composition of the legal system, based on the criterion of classification - "subject of legal regulation" and the peculiarities of the instruments of the digital economy. The role of information law, as a structural element of the system of national law, in ensuring law and order in the digital economy is clarified on the basis of model examples. The existing information concept of law in the new conditions of today is developed. It is proved that the "information" of the system of national law is manifested 
both in the information essence of any norm of law (civil, administrative, financial, labour and other law) and in the strengthening of the interaction of any rule of law with the norms of information law.

\section{REFERENCES}

1. Про Основні засади розвитку інформаційного суспільства в Україні на 2007-2015 роки : Закон України від 9 січня 2007 року. URL: https://goo.gl/oPp05P (дата звернення: 15.01.2021).

2. Про Рекомендації парламентських слухань на тему: «Законодавче забезпечення розвитку інформаційного суспільства в Україні» : Постанова Верховної Ради України від 3 лютого 2017 року №1565-VII. Відомості Верховної Ради Украӥни. 2014. № 33. Ст. 1163.

3. Про схвалення Концепції розвитку цифрової економіки та суспільства України на 2018-2020 роки та затвердження плану заходів щодо іiі реалізації : Розпорядження Кабінету Міністрів України від 17 січня 2018 p. № 67-p URL: https://goo.gl/zoUzYE (дата звернення: 15.01.2021).

4. Угода про асоціацію між Україною, 3 однієї сторони, та Свропейським Союзом, Свропейським співтовариством 3 атомної енергії і їхніми державами-членами, з іншої сторони : Міжнародний документ від 27 червня 2014 року. URL: https://goo.gl/6BtyуH (дата звернення: 15.01.2021).

5. Теорія держави і права. Академічний курс : підручник / за ред. О.В. Зайчука та ін. 2-е вид., перероб і допов. Київ : Юрінком Інтер, 2008. $688 \mathrm{c}$.

6. Луць Л.А. Європейські міждержавні правові системи та проблеми інтеграції з ними правової системи України (теоретичні аспекти) : монографія. Київ : Ін-т держави і права ім. В.М. Корецького НАН України, 2003. 304 с.

7. Алексеев С.С. Советское право как система: методологические принципы исследования. Советское государство и право.1974. № 7. C. $15-22$.

8. Алексеев С.С. Право и правовая система. Советское государство и право. 1980. № 1. С. 4-9.

9. Керимов Д.А. Философские основания политико-правовых исследований. Москва : Изд-во «Мысль» 1986.332 с.

10. Колосова Н.М. Интегративная функция правовой системы : автореф. дисс ... канд. юрид. наук. Москва, 1990. 22 с.

11. Рассолов М.M. Теоретические проблемы управления и информатики в сфере права : автореф. дисс... канд. юрид. наук. Москва, 1990. 23 с.

12. Тихомиров Ю.А. Публичное право. Москва : Издательство БЕК, 1995. $486 \mathrm{c}$.

13. Венгеров А.Б. Теория государства и права : учеб. для юридических вузов. 8-е изд. Москва : Изд-во «Омега-Л», 2011. 607 с. 
14. Мельник Р.С. Система адміністративного права України : монографія. Харків : Вид-во Харків. нац. ун-ту внутр. справ, 2010. 398 с.

15. Арістова І.В., Карпик Ю.А. Вплив цифрової економіки та європейської інтеграції на правотворчість у сфері інтелектуальної власності в умовах розбудови інформаційного суспільства та інформаційного законодавства в Україні. Modern researches: progress of the legislation of Ukraine and experience of the European Union : Collective monograph. Riga : Izdevniecība "Baltija Publishing", 2020. P. 1. P. 255-288. DOI: 10.30525/978-9934-588-43-3/1.16 URL: http://dx.ua/8eBpr

16. Арістова I.В., Курило В.I., Калугін О.Ю. Впровадження інформаційно-комунікаційних технологій в аграрний сектор економіки України: організаційно-правовий аспект : монографія ; за заг. ред. I.В. Арістової. Київ : Редакційно-видавничий центр НУБіП України, 2014. $193 \mathrm{c}$.

17.Бєляков К.І. Інформатизація в Україні: проблеми організаційного, правового та наукового забезпечення : монографія. Київ : КВІЦ, 2008. 576 с.

18. Кудь О.О., Кучерявенко М.П., Смичок Є.М. Цифрові активи та їх економіко-правове регулювання : монографія. Харків : Право, 2019. $384 \mathrm{c}$.

19. Что такое блокчейн простыми словами. URL: https://prostocoin.com/blog/blockchain-guide (дата звернення: 15.01.2021).

20. Арістова I.В. Теоретико-правові засади інформаційних правовідносин. Юридична відповідальність за правопорушення в інформаційній сфері та основи інформаційної деліктології : колективна монографія. Київ : КВУЦ, 2019. С. 36-62.

21. Венгеров А.Б. Право и информация в условиях автоматизации управления (теоретические проблемы) : автореф. дис. ... д-ра юрид. наук. Москва, 1975. 26 с.

22. Арістова I.B., Чернадчук В.Д. Концепція інформаційних правовідносин: сутність та особливості використання у сфері банківської діяльності. Інформація і право. 2012. № 3 (6). С. 47-56.

23. Копылов В.А. Информационное право : учебник. Москва : Юристь, 2002. 456 с.

24. Кохановська О.В. Основні теорії у сфері інформаційних правовідносин: концепція інформаційних прав як приватноправового інституту і теорія інформаційного права як галузі права у сучасній правовій доктрині України. Приватне право. 2013 № 1. С. 186-200.

25. Арістова I.В. Проблема взаємодії галузей національного права: методологічні засади. Матеріали IV Всеукраїнської науково-практичної конференції «Актуальні питання вітчизняної юридичної науки» (м. Суми, 13-14 квітня 2017 р.). Суми : вид-во СНАУ, 2017. С. 42-45.

26. Анохин П.К. Принципиальные вопросы общей теории функциональных систем : монография. URL: https://goo.gl/hgbmvz (дата звернення: 15.01.2021). 
27. Скакун О.Ф. Теорія держави і права (Енциклопедичний курс) : підручник. Вид. 2-е, перероб. і доп. Харків : Еспада, 2009. 752 с.

28. Арістова I.В. Система права України в умовах інформаційного суспільства та цифрової економіки. Приватне та публічне право. 2020. № 3. C. 44-51. DOI: https://doi.org/10.32845/2663-5666.2020.3.9 URL: http://pp-law.in.ua/archive/3_2020/11.pdf

29. Чернадчук Т.О. Актуальні питання інформаційних правовідносин у банківській сфері: монографія ; за заг. ред. І.В. Арістової. Суми : Вид-во СНАУ, 2011. 162 с.

30. Чернадчук Т.О. До питання захисту інформації, віднесеної до податкової таємниці. Публічне право. 2016. № 4 (24). С. 109-115.

31. Чернадчук Т.О. До питання концепції інформаційних правовідносин в бюджетній сфері. Публічне право. 2017. № 2 (22). C. $109-115$.

\section{Information about the authors:} Aristova I. V., Doctor of Laws, Professor, Head of the Department of Administrative and Information Law Sumy National Agrarian University 160, Herasym Kondratiev str., Sumy, 40021, Ukraine

Chernadchuk T. O.,

Ph. D. in Law, Associate Professor, Associate Professor at the Department of Administrative and Information Law

Sumy National Agrarian University 160, Herasym Kondratiev str., Sumy, 40021, Ukraine 